Riga, Latvia, March 20, 2020

\title{
TESTING IN THEORY AND PRACTICE OF MODERN EDUCATION
}

\section{Viktoriia Koretska $^{1}$}

\section{DOI: https://doi.org/10.30525/978-9934-588-39-6-8}

The current and priority problem of the modern informational society is to improve the quality of education as an important condition for the development of a pan-European education space. Achieving a high level of quality of education is possible by means of knowledge control as the most important component of the pedagogical system and educational process. Control should facilitate the development and improvement of the pedagogical process. The importance of control and evaluation in the modern educational process is drawn to the attention by many educators, such as A.M. Aleksiuk, Y.K. Babanskyi, V.V. Voronov, S.V. Goncharenko, I.P. Pidlasyi, I.F. Kharlamov and others.

Control as a compulsory component of the learning process should take place at all studying stages, and is especially relevant after studying the program section or completion of the degree. The level of present knowledge must meet the requirements specified in the educational standard of the curriculum in the subject [2, p. 352]. Traditional control methods are often combined with an effective method of testing. Properly drawn tests are a necessary component of the learning process.

Scientist V. Kadnevskyi noted that in the modern world, tests have become an important component in the life of society. Their universalism, breadth of application, high level of objectivity of the obtained results make it possible to define the tests as a phenomenon of human civilization [6].

Nowadays there are many types of tests available, so it is rather difficult to give a universal definition for all of these types. Scientists do not agree on both the definition of «test» and the exact time and place of origin of the first tests. The traditional test in our understanding is a series of questions with selected sets of answers to them. However, if one considers the etymology of the word «test» more broadly, it means an examination, a checkout. Exactly such tests were in antiquity. And in ancient civilizations, these were, first of all, tests, checks for a person who wants to take a certain position. In science, this stage of testing development is called pre-scientific. It originated at the dawn of human civilization and lasted until the end of the nineteenth century. It is impossible to determine the exact date of the tests. In particular, V. Avanesov pointed out that «... any attempt to determine the exact time of

\footnotetext{
${ }^{1}$ Volodymyr Vynnychenko Central Ukrainian Pedagogical University, Ukraine
} 
the tests appearing is reminiscent of the desire of geographers to find the exact beginning of a large river that flows from plenty of streams from a wide swamp» [5]. V. Avanesov's research in «Theory and Practice of Pedagogical Measurements» is worth attention; in it the author focuses on the definition of pedagogical testology, test, its classification (traditional and non-traditional tests), structure, separately considers the concept of "pedagogical test», its content, basic principles of test development, etc. [3]. In his work «Form of Test Tasks» V. Avanesov defines the pedagogical test as a system of parallel tasks with gradually increasing degree of difficulty, of a specific form that allows to measure the level and evaluate the structure of students' preparation qualitatively and effectively [5].

In the Ukrainian pedagogical dictionary the term «test» is defined as a system of techniques for testing and evaluation of individual mental traits and characteristics of a person; the task of a standard form, the fulfillment of which must reveal the presence of certain knowledge, skills, abilities or other psychological characteristics - interests, emotional reactions, etc. [4, p. 329].

Research and study of the concept of test in modern education is growing significantly. Nowadays the Ukrainian education is experiencing the formation and further development of standardized testing technology, which is used in all professional testing in most developed countries. The complexity of introducing the test as a measurement tool into the learning process is explained by the necessity for a serious preparatory phase. In addition, developing a qualitative test requires a specialist with knowledge of test theory, skills and experience in analyzing results and evaluation learning achievements of the students and pupils.

One of the main elements of assurance in education quality is external independent assessment (EIA) of students' educational achievement. External Independent Assessment is one of the most widely used and effective student evaluation systems in the world, allowing both final assessment and selection for higher education institutions. The main prerequisite for the introduction of external independent assessment in Ukraine were the proclamation of the National Doctrine of Development of Access to Quality Education for All Citizens of Ukraine. The main goal of the Ukrainian education system is to create favorable conditions for the development and self-realization of each personality, to form generations that are able to learn throughout life, to create and develop the values of civil society. One of the priorities of the state policy in the development of education is the creation of equal opportunities for children and young people in obtaining qualitative education [1].

According to the Decree of the President of Ukraine of July 4, 2005 «On Urgent Measures to Ensure the Functioning and Development of Education in Ukraine», since 2006, a national system of external independent assessment 
has been implemented in Ukraine, which is based on the model of external standardized testing. In 2006, the Ukrainian Center for Educational Quality Assessment was established, which provides assessment and certification of graduates' academic achievement.

In 2006, the Ukrainian Center for Educational Quality Assessment, supported by ICE «Center for Testing Technologies and Education Quality Monitoring» and the International Foundation «Vidrodzhennia», conducted time an external independent assessment of educational achievement for the first at the national level, involving 41,000 graduates of general education institutions (in total 82,000 tests in the Ukrainian language, mathematics and history). Since 2008, admission to higher education institutions is carried out only by the results of external independent evaluation. Therefore, we can state that a new stage of testing implementation has begun in our country. There is a process of revival of state testology and test culture. The rather widespread use of tests in psychology, professional selection, medicine, and in recent years and in the educational system indicates that test technologies in Ukraine have become a mandatory attribute of modern pedagogical diagnostics, so nationwide testing of educational success, the level of assimilation of the content of education is the most important nowadays.

\section{References:}

1. Ministerstvo osvity i nauky Ukrajiny Nasionaljna doktryna rozvytku osvity (2018). [National Doctrine of Educational Development].

2. Pidkasystyy, P. I. (2006). Pedagogika [Pedagogy]. Moscow: Pedagogicheskoe obshchestvo Rosii. (in Russian)

3. Avanesov, V. S. (2005). Teoriya i praktika pedagogicheskikh izmereniy (materialy publikatsiy) [Theory and practice of pedagogical measurements (materials of publications)]. Moscow: TSP y MNO TS·HTU. (in Russian)

4. Honcharenko Semen (1997). Ukrajinsjkyj pedaghoghichnyj slovnyk [Ukrainian Pedagogical Dictionary]. Kyiv: Lybid'. (in Ukrainian)

5. Avanesov, V. S. (2005). Forma testovykh zadaniy [Form of test assignments]. Moscow: Tsentr testyrovaniya. (in Russian)

6. Kadnevskyi, V. M. Testovaya kul'tura kak fenomen tsivilizatsii [Test culture as a phenomenon of civilization]. Retrieved from: http://www.oim.ru (accessed 02.03.2020). 